\title{
The Position of Consideration in Nepal: a Study of Theories, Cases, and Laws
}

\author{
Laxmi Sapkota*
}

\begin{abstract}
Lawful consideration is one of the essential elements of a valid contract. However, The National Civil Code, 2017 A.D. (2074 B.S.) has not included a definition of consideration, and it has not stated the necessity of consideration in Nepal in a particular section. Nevertheless, it seems that the Code has realized the importance of lawful consideration in the provisions of contracts of rent, wage and hire purchase. The Code has also stated unjust enrichment, under which one party should not enrich bimself or herself at the cost of others or other's property. Conversely, the now-repealed Contract Act, 2000, in its section 2(d), had defined consideration and stated that consideration must be lawful in section 13(k). In the cases decided by the Supreme Court of Nepal Bhagwan Lal Shah v. Harka Lal Giri and Chitra Bahadur Karki; Proprietor of Manakamana Construction and Concerns Pvt. Ltd v. Maniram Aggrawal, Proprietor of Aggrawal Industries Pvt. Ltd.), the Supreme Court has issued the precedent stating the importance of consideration in Nepal in regard to Contract Act, 2000 which has now been repealed and replaced by The National Civil Code 2017. Additionally, different theories of the contract like bargain theory, realistic interpretation, theory of reciprocity, 'nundum pactum' theory and 'no consideration no contract' theory also emphasize the importance of consideration in Contract. Finally, this research paper has proven that consideration is essential in Nepal, thereby stating the theories of consideration, the legislative provisions, and the cases. Furthermore, the researcher came to the conclusion that the lawful consideration is essential in Nepal and it should be dealt with like oxygen to bumans and whether written or not, must be implicitly understood. The word 'consideration' not explicitly being mentioned in law should not create confusion that a contract can happen without lawful consideration.
\end{abstract}

\section{Introduction}

Consideration is one of the essential elements of a valid contract. There is debate and discussion in regards to the necessity of consideration in Nepal. The Contract Act, 2000 A.D. (2056 B.S.) was not clear in the necessity of consideration in Nepal. However, the Supreme Court had issued the precedent stating 'no consideration no contract'. Now the law has been repealed by the act of parliament, that is, The National Civil Code, 2017

* Laxmi Sapkota is an Assistant Professor at Kathmandu School of Law. She can be reached at laxmi.sapkota@ksl.edu.np. 
A.D. (2074 B.S.). This legislation has not included the definition of consideration and has also omitted an earlier provision under which a contract with unlawful consideration was void. The Code has also not stated the necessity of consideration in the contract. The author in this paper has attempted to undertake a comparative study and show the consideration condition. The paper concludes that consideration is one of the essential elements of a valid contract, and it is necessary for Nepal.

\section{Meaning and Definition of Consideration}

A set of promises between an offeror and offeree with the inclusion of some consideration is an agreement. If an agreement is enforceable by law, then it is called a contract. ${ }^{1}$ The National Civil Code (2017) 2074 states, "If an agreement enforceable by law is concluded between two or more persons to do or abstain from doing any act, then it is said that the contract is concluded". ${ }^{2}$ Section 504(2) of the same Code states, 'A contract is concluded once the person to whom an offer has been made by another person communicates his or her acceptance thereto'. ${ }^{3}$ Adding to it, Section 504(3) states, 'Once a contract is concluded, a binding legal relationship is created between the parties to it'. ${ }^{4}$

To conclude a valid contract, there must be two or more than two parties or plurality, offer and acceptance, lawful consideration, lawful object, the capacity of the party (parties should not be minor, should not be a person of unsound mind and person disqualified by law), the contractual intention of parties, free consent (should not be under coercion, undue influence, fraud, misrepresentation and mistake), not expressly declared void by law, ${ }^{5}$ certainty and possibility ${ }^{6}$ and legal formalities.

Arbind Majamdar on behalf of Damodor Ropeway and Construction Company v. Nepal Government, Finance Ministry, NKP 2073 (2016), volume 5, Decision no. 9591, laid down the principle that 'The contract is the agreement drafted by the concerned parties of the contract that is binding to them'; Bijay Kumar Basnet v. Mayor Keshav Sthapit, Kathmandu Metropolitan, NKP 2059, laid down the principle that an, agreement between two or more than two parties with conditions is a contract.

Muluki Dewani Sambita Ain 2074 (The National Civil Code 2017), s. 504(1).

Ibid, s. 504(2).

Ibid, s. 504(3).

Ibid, s. 517; Contract restraining exercising profession, trade or business, a contract in restraint of a marriage other than one prohibited by the law, a contract restraining any one from enjoying the facilities being enjoyed by the public is a void, a contract restraining legal right of any person from being enforced by a court is void., a contract concluded contrary to law or on a matter prohibited by the law in force, a contract made for an immoral purpose or against public order or public interest, a contract which cannot be performed because the parties thereto do not exactly ascertain or know about the matter, in relation to which it has been concluded, a contract the performance of which is impossible at the time of its conclusion or a fictitious contract, a contract which is vague because of its subject matter being incapable of giving a reasonable meaning, a contract concluded by a person not competent to make contract, a contract with an illegal purpose, a contract concluded by mistake of both parties as to the essential fact of the contract at the time of its conclusion.

Chitra Bahadur Karki v. Maniram Aggrawal, NKP 2071 (2014), volume 10, Decision no. 9264; The terms and conditions of the contract should be possible to perform. If the contract is not possible to perform then it is not considered as a contract. Here, this case, the party Chitra Bahadur Karki does not have the right, capacity, or is not the concerned person to give the tender agreement to Maniram Aggrawal. Chitra 
Lawful consideration is one of the most important elements of a contract. A contract is a deed made between two parties to do or not to do something for consideration. ${ }^{7}$ Consideration is derived from the Latin word 'considerationem', which means, 'taking into account. ${ }^{8}$ In general, consideration is believed to be an act of giving something and taking something in return. So, consideration means something in return between the offeror and the acceptor in the contract. ${ }^{9}$ Consideration implicates a detriment to the party delivering it or a benefit to the party obtaining it. The benefits and detriments of both parties are significant to them in a contract.

For instance, $\mathrm{X}$ wants to make a lease contract of his land at Rs. 50,000 to Y. The consideration for $\mathrm{X}$ is land on lease, and the consideration for $\mathrm{Y}$ is the money. This means what the parties get in return is the consideration for the parties of the contract. Here, the detriment to $\mathrm{X}$ is land on lease, and benefit is the amount received for it, and the detriment to $\mathrm{Y}$ is the money given, and benefit is the land on lease. ${ }^{10}$

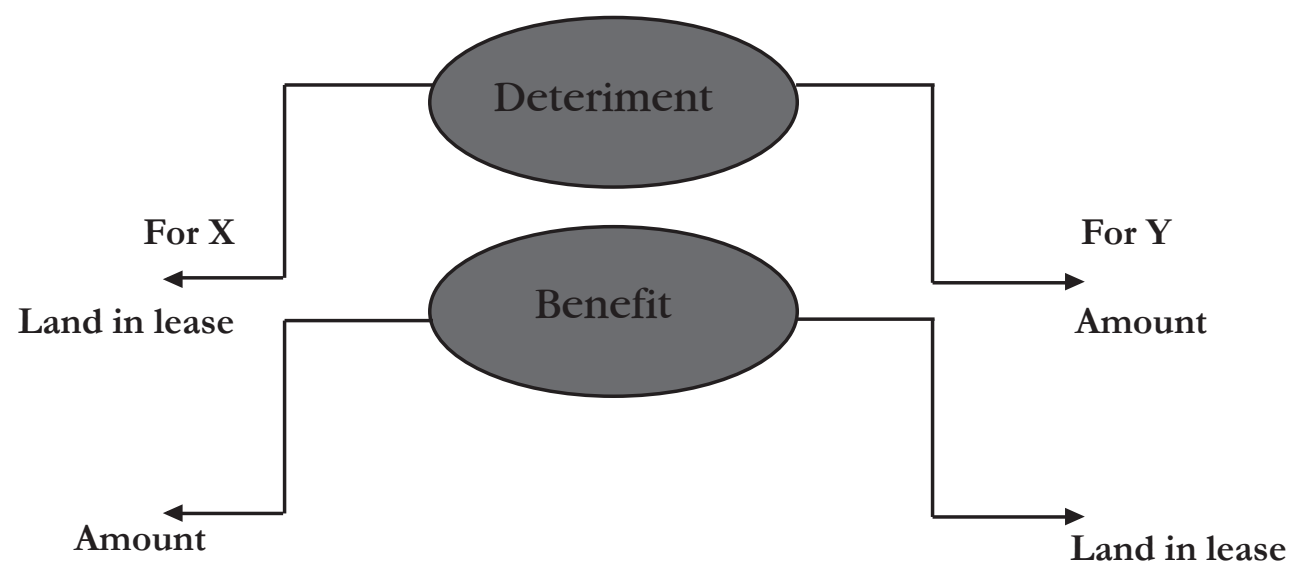

Therefore, consideration refers to what one party to an agreement gives or promises in exchange for what has been given or promised from the other side in the contract. ${ }^{11}$ Both parties are entitled to get something in return of something ${ }^{12}$; it is the value for which the other's promise is credited. Therefore, an object under consideration must

Bahadur Karki is also one of the competing parties to get the tender. Even if Chitra Bahadur Karki's offer to get the tender is accepted, he could not give that tender to Maniram Aggrawal. Therefore, the pleading of Chitra Bahadur Karki to give the tender to Maniram Aggrawal is impossible to perform.

7 Prithivi Bahadur Maharjan v. Birat Bahadur Khadka, NKP 2064 (2007), volume 8, Decision no. 7874.

8 Online Etymology Dictionary, available at https://www.etymonline.com/word/consideration, accessed on 30 April 2021.

$9 \quad$ Laxmi Sapkota, Contract Law, Lex and Juris Publication Pvt.Ltd, Bhaktapur, 1st edition, 2019, p. 85.

$10 \quad$ Ibid, p. 86.

11 Stone, R., Principles of Contract Law, Cavendish Publishing Limited, London, $4^{\text {th }}$ edition, 2001, p. 49.

12 The Latin Maxim 'quid pro quo' means something in return of something. Consideration may take the form of goods, services, money or financial instruments. Such consideration amounts to a contract in which something is being provided and something of equal value is returned in exchange. 
always have value in the eyes of the law.

Consideration relies on what one party to an agreement is giving or promising in exchange for what is being given or promised from the other side. ${ }^{13}$ An object under consideration might not always be money; it can also be of services, personal property, real property, promise to act or promise to abstain, promise to refrain from the act, financial instruments or in any feasible form in which a give and take relationship can be established.

There are two notions of consideration. One is the broad notion, which argues that consideration is essential to make the promise legally enforceable. And, consideration in the restrictive concept means the bargain between the offeror and offeree, which means there must be something in return.

\section{Features of Consideration}

A contract without consideration is taken as a valid contract in Nepal. However, one of the essential elements of a contract is to have consideration. The following are the features of consideration:

a. Consideration must have value in the eyes of the law: It is essential that the consideration must have value in the eyes of the law and should not be something that can be found easily. For example, consideration cannot be of a small invaluable stone. ${ }^{14}$

b. Consideration must be mentioned in the contract: The consideration must be mentioned in the contract paper before signing it; the parties must be able to see and check it.

c. Consideration can be present or future: The consideration can be made of present or future conditions. For example, if $\mathrm{R}$ agrees to buy some goods from $\mathrm{S}$. Here, $\mathrm{R}$ gives the money, and $\mathrm{S}$ receives goods. Future consideration means the consideration which would be shown in the future to one of the parties of the contract. ${ }^{15}$

d. Past consideration is not considered: Past consideration is not taken as lawful consideration in English law as the terms and conditions of the contract are already performed and because consideration cannot be retrospective. However, in the case of Nepal, past consideration is also taken as consideration.

e. Consideration needs to be sufficient but need not necessarily be adequate: Another essential element of the consideration is that even though a review might not be adequate, it should be sufficient. The concept of sufficiency, however, is subjective.

\footnotetext{
$13 \quad$ Stone (n 11), p. 49.

14 Sapkota (n 10), p. 87.

15 Ibid, p. 88.
} 


\section{Types of Consideration}

Different kinds of consideration may be located which may be categorized on numerous bases. Two key bases for categorizing consideration are provided below:

a. On the basis of promise in respect to time: On the basis of promise in time, the following are the types of consideration.

\section{i. Future (Executory) Consideration:}

In future consideration, the promise to fulfil the respective obligations by both parties shifts to the future. In such a type, only the promise is made at present by both parties, but its implication can only be seen in the future. This type of consideration arises in the unilateral contract and may depend upon the fulfilment of conditions. The liability under this consideration lies on both parties.

Example: 'A' promises to deliver goods at a certain price. In return for the promise, 'A' gets payment from 'B'.

ii. Present (Executed) Consideration: In this type of contract, both parties simultaneously perform their respective obligations. Here, the promise is made and is executed both at the same time by the parties under their respective commitments. The promise made and the acts carried out under consideration are integral and co-related parts of the same transactions. ${ }^{16}$ This type of consideration generally arises in a bilateral contract. For example, someone can order a pizza through any means of communication and pay the amount when he/she receives the pizza.

\section{iii. Past Consideration:}

When an act is connected with the past happening, but the reward is given solely depending on the beneficiary party's will in the absence of the expectation of the action performed, it is past consideration. One party has already suffered a detriment, but the benefit is remaining. Under it, consideration for the present promise is made before the date of the promise. ${ }^{17}$

English Law does not recognize past consideration, stating past consideration is no consideration at all. ${ }^{18}$ However, Indian law has recognized past consideration. ${ }^{19}$ Exemplifying past consideration, if A does a work voluntarily for $\mathrm{B}$ and if $\mathrm{B}$ gives something to ' $\mathrm{A}$ ' in future for the work done by ' $\mathrm{A}$ ', then that is called past consideration.

\footnotetext{
16 Jack Qc Beatson, Anson's Contract Law, Oxford University Press, New York, 28 ${ }^{\text {th }}$ edition, 2002, p. 93.

17 S.B. Karki, B.P. Mishra, \& D.N. Parajuli, Business Law BBS $3^{\text {rd }}$ Year, Platinum Publication Pvt. Ltd., Kathmandu, 2016, p. 56.

18 Steve Thel \& Edward Yorio, 'The Promissory Basis of Past Consideration', Virginia Law Review p 1045, volume 78:5, 1992.

19 Indian Contract Act, 1872, India, s 2(d): When, at the desire of the promisor, the promisee or any other person has done or abstained from doing, or does or abstains from doing, or promises to do or to abstain from doing, something, such act or abstinence or promise is called a consideration for the promise.
} 
b. On the basis of action: On the basis of action, the following are consideration types.

i. Positive consideration: A contract made to do something is a positive consideration. For instance, the delivery of goods at a certain time is a positive consideration. Here, the parties get something for doing something.

ii. Negative consideration: Contract made not to something is negative consideration. An example of negative consideration is not to use the land for irrigation. A contract done not to work in another company for a certain period of time that is not declared void by the law is an example of negative consideration.

\section{Rules Regarding Consideration}

The rules regarding consideration are:

\section{a. Consideration must move at the desire of the promisee:}

The general rule of consideration is that it must have been done at the desire or request of the promisee. If it is done at the instance of a third party or without the desire of the promisee, it is not a good consideration. For example, if A offers to buy something of $\mathrm{B}$, then B's desire prevails for consideration.

\section{b. Consideration can be of past, present and future:}

Asmentioned in detail above, both presentand future considerations are undoubtedly recognized by contract law as valid forms of consideration. However, in the case of past consideration, there are some dissenting opinions. Past consideration is not taken as sufficient consideration. ${ }^{20}$ By past consideration, the courts mean an act that could have obliged as consideration if it had been negotiated for at the time, but that was not the subject of negotiation. ${ }^{21}$ Orthodoxy asserts that "past consideration is no consideration at all', providing with exceptions. ${ }^{22}$ However, in modern times, the court opines that promises made for past consideration can be enforced. A promise can be enforced if there is a material benefit involved and that the promise of the benefit occurred after consideration. For example, A's neighbor's home is on fire. A ran into the home and saved his neighbor but experienced serious burns in the process. To make up for his injuries, the neighbor agrees to pay him a weekly gross for the rest of his life. However, his neighbor passes away, and their estate decides to no longer pay A's gross. A can enforce the promise, as A's gross was based on a material benefit to his neighbor. Consideration must be given in return for the specific promise of the other party, i.e., it cannot

\footnotetext{
20 P.S. Atiyah, Consideration in Contracts: A Fundamental Restatement, Australian National University Press, Canberra, 1991.

21 Don Mayer et al., The Law, Sales, and Marketing, 2012, available at https://2012books.lardbucket.org/ books/the-law-sales-and-marketing/, accessed on 30 April 2021.

22 An act already performed may be valid consideration for subsequent promise if: Act done at promisor's request; Parties understood at time that the act was to be compensated for;
} 
be past. ${ }^{23}$ Past consideration is sufficient when it is provided at the request of the promisor. ${ }^{24}$ Past consideration is not a consideration at all. ${ }^{25}$

\section{c. Consideration should be sufficient but may not be adequate}

Adequacy, in consideration, means something in return should be of equal value to something given. The adequacy of the consideration is for the parties to consider at the time of agreeing when it is required to be enforced. If the dispute arises, the court only sees whether the parties' consent to the promise was free or not. Sufficient means something in return should satisfy the contracting party.

\section{d. Consideration must be real}

Although consideration need not be adequate, it must be real, competent, and of some value in the eyes of the law. A contribution to charity is without consideration. Therefore, it is not a real consideration. For example, A promises to give B's dead son life and if B pays him Rs. 500. Here, the consideration is invalid in the eyes of the law, meaning it is impossible to attain.

\section{e. Consideration must not be illegal, immoral or opposed to public policy.}

Consideration that is illegal, immoral, or opposed to any public policy is invalid in the eyes of the law. The National Civil Code, 2017, section 5172 (f) states that the terms and conditions of a contract should not be illegal, immoral and opposed to public policy. For example, A agrees to give certain grams of Narcotic drugs to B for a certain amount. It is illegal considering drugs are illegal in Nepal and could not form a valid contract.

\section{Exception of the consideration}

Generally, every contract is done for some considerations; however, sometimes, there can be a contract without consideration, which is called an exception to consideration. Some of these exceptions are discussed below:

a. Gift (reward, prize or tip): The National Civil Code, 2017 states that a person can grant a property (gift) in which the person has right and ownership to another person as a reward, prize or tip without consideration. ${ }^{26}$ Gift can be effective immediately or after a certain period or after the death of its maker. ${ }^{27}$ If a gift becomes effective only after the death of the maker, then he or she can execute a testamentary gift. ${ }^{28}$ Any gift made is ipso facto void if a person does not accept the

\footnotetext{
23 Roscorla v. Thomas, England and Wales High Court, 1842, 114 ER 496.

24 Lampleigh v. Braithwait, England and Wales High Court, 1615, 80 ER 255.

25 Prithivi Narayan Mabarjan v. Biraj Khadka, NKP 2064 (2007), volume 8, Decision no. 7874.

26 The National Civil Code (n 3), s. 406(2).

27 Ibid, s. 406(3).

28 Ibid, s. 406(4).
} 
gift, ${ }^{29}$ if a person dies before accepting the gift, ${ }^{30}$ if the unborn baby dies, in case of property gifted to the unborn child, ${ }^{31}$ if the gifted property is destroyed before the gift becomes effective. ${ }^{32}$ For example, a person can give his/her property as a gift by fulfilling the legal requirement without any consideration.

b. Donation: Donation is another exception to the rule, 'no consideration no contract'. The National Civil Code, 2074 states that a person can grant a property (donation) having ownership to another person or for any religious, social, public or community purpose without any consideration. ${ }^{33}$ The donation can be effective immediately or after a certain period or after the death of its maker. ${ }^{34}$ If a donation becomes effective only after the death of the maker, then he or she can execute a testamentary donation. ${ }^{35}$, Any donation made, if the person does not accept it, then is ipso facto void $^{36}$, if a person dies before accepting the donation ${ }^{37}$, if the unborn baby dies, in case of property donated to the unborn child, ${ }^{38}$ if the donated property is destroyed before the donation becomes effective. ${ }^{39}$ For example, a person may donate his/her properties or goods to other parties where there is no consideration, and both parties do not share the benefit and detriment relationship.

c. Payment of the compensation for the past work: If someone pays the compensation for the work done in the past and even though the person who receives the compensation is benefited, there is nothing detrimental for him/her. So, it can be taken as an exception to the consideration.

d. Promise to pay the time-barred debt: In the case of signed and written debt, the promise to pay a time-barred debt is enforceable even without consideration.

e. Agency Contract: In an agency contract, the agent works on behalf of the third party's principal. The agency contract is also an exception to the consideration.

\section{Necessity of Consideration in Nepal}

The necessity of consideration in Nepal can be proven from the theories, the legislative provisions and the judicial decisions which are further discussed below: 


\begin{tabular}{|c|c|c|}
\hline Theories & Legislative provisions & Judicial decisions \\
\hline $\begin{array}{l}\text { The following theories } \\
\text { of the consideration } \\
\text { stated the importance of } \\
\text { the consideration: } \\
\text { a. Bargain theory } \\
\text { b. Realistic interpretation } \\
\text { c. Theory of reciprocity } \\
\text { d. Nundum Pactum } \\
\text { e. No consideration no } \\
\text { contract }\end{array}$ & $\begin{array}{l}\text { Necessity } \\
\text { consideration in } \\
\text { a. In the case of lease } \\
\text { contract } \\
\text { b. In the case of hire- } \\
\text { purchase contract } \\
\text { c. In the case of wages } \\
\text { for employment in work } \\
\text { d. Inclusion of the } \\
\text { provision of the unjust } \\
\text { enrichment }\end{array}$ & $\begin{array}{l}\text { The necessity of the } \\
\text { consideration in Nepal } \\
\text { is pronounced in the } \\
\text { following case by the court } \\
\text { and it has relevance after } \\
\text { the promulgation of the } \\
\text { National Civil Code, } 2017 \\
\text { (2074) } \\
\text { Bhagwan lal Shah v. Harka } \\
\text { Lal Giri, NKP } 2062 \text { (2005), } \\
\text { volume 11, Decision no. } \\
7624 \text {. } \\
\text { Chitra Babadur Karki, Properitor of } \\
\text { Manakamana Construction and Concerns } \\
\text { Pvt. Ltdv. Maniram Aggrawal, Properitor } \\
\text { of Aggrawal Industries Pvt. Ltd., NKP } \\
2071 \text { (2014), volume 10, Decision no. } \\
9264\end{array}$ \\
\hline
\end{tabular}

\subsection{Theories of consideration}

The following are the theories of the consideration that literally and logically states the importance and necessity of the consideration:

\section{a. Bargain theory:}

A bargain is a part of human nature. The value of any object comes out from bargaining. Hence, under contract law, no bargain means no consideration. According to consequentiality, bargaining ensures that goods are valued at their just value. ${ }^{40}$ Additionally, bargain is done for the consideration. Exceptions to this theory are the standard form of contract and unilateral contract. In such contracts, no bargaining is implied; it is a one-sided contract drafted by only one party. ${ }^{41}$

b. Realistic interpretation: Consideration can be best understood as a requirement that there is a 'reason' to enforce a contract ${ }^{42}$ and must be something of value. If the realistic interpretation of the contract is done, then it can be understood that the interpretation of the contract is done for consideration.

c. Theory of reciprocity: Under consideration, a promise is not enforced unless the object under consideration is of some value to the other party. This theory implies that consideration must rely on something which the law must assume to be of some value to the promisor ${ }^{43}$ in exchange of reciprocal and proportional promise.

\footnotetext{
$40 \quad$ Lon L. Fuller \& Melvin Aron Eisenberg, Basic contract Law, West Group, $6^{\text {th }}$ edition, p. 6.

41 Sapkota (n 10), p. 88.

$42 \quad$ Atiyah(n 20), p. 181.

43 Henry Winthrop Ballantine, 'Mutuality and Consideration', Harvard Law Review p 121, volume 28:2, 1914.
} 
For example, the exchange of a newly purchased Ford Car (costing Rs. 1,000,000) for a piece of chocolate does not create a reciprocal consideration. Hence, the theory of reciprocity also focuses on the necessity of the consideration.

\section{d. No consideration, no contract}

One of the essential theories of contract law is 'no consideration, no contract'. Consideration is significant to constitute a valid contract. There must be a promise in exchange for something valuable in a contract, and based on that promise, both parties get something beneficial or detrimental. So, the benefit or detriment of the parties in any agreement is a consideration.

\subsection{Cases decided by the Supreme Court}

The following are the cases in which the Supreme Court has given the precedent in favour of the necessity and importance of the consideration in Nepal.

\section{a. Bhagwan lal Shah v. Harka Lal Giri, ${ }^{44}$}

In this case there was, the agreement paper signed by two parties stated that the land registered in the name of the plaintiff of land. No. 556, 558 is given to construct the cinema hall of length $127 \mathrm{ft}$. and breadth $87 \mathrm{ft}$. The agreement paper that allowed the applicant to make cinemas in the defendant's land did not mention the duration of the operation. Also, there were no provisions regarding the payment of rent. Hence, the supreme court indicated that the paper which lacks the consideration does not get the validity of the contract paper.

b. Chitra Bahadur Karki, Proprietor of Manakamana Construction and Concerns Pvt. Ltd v. Maniram Aggrawal, Proprietor of Aggrawal Industries Pvt. Ltd, ${ }^{45}$

In this case, Chitra Bahadur Karki supplied the necessary food item to Shree Shumsher gud dal Bake Dadeldhura and its unit for the financial year 2059/2060 for Rs. 12,923,753. However, agent Mani Ram Aggrawal got the tender for the financial year 2060/2061. Consequently, Chitra Bahadur Karki had suffered a loss of Rs. 1,300,000 and Rs. 884,759 in 2059/60 and he claimed that Maniram Aggrawal in total has to pay Rs. 2,184,721 within 30 days to him.

Court decided that the agreement paper is not a contract paper because it lacks the consideration and the possibility of performance. So, Maniram Aggrawal is not liable to pay the amount to Chitra Bahadur Karki.

Supreme Court, explicitly stated the followings precedent:

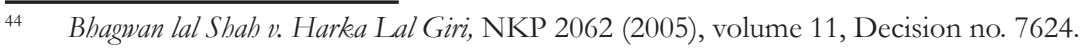

45 Chitra Bahadur Karki, Properitor of Manakamana Construction and Concerns Pvt. Ltd v. Maniram Aggrawal, Properitor of Aggrawal Industries Pvt. Ltd., NKP 2071 (2014), volume 10, Decision no. 9264.
} 
Firstly, the court stated that a contract is an agreement between two or more parties to do something or not to do something that the law must enforce. Agreement or consent alone is not sufficient to be a valid contract; it needs other essential elements. An agreement enforceable by law is a contract.

Secondly, the court stated that the consent paper or agreement paper must be clear. The unclear sentence or language used in consent paper or agreement paper creates difficulty in knowing the party's rights and obligations. The unclear agreement makes the contract legally unenforceable.

Finally, the court stated that, according to the principle, 'no consideration no contract', for a valid contract. Therefore, consideration is one of the essential elements of a valid contract. As both the parties promise to each other. According to the promise, parties get something and are decremented something. The benefit and detriment is a consideration in the contract.

\subsection{Provision of the importance of consideration in, The National Civil Code, 2017}

When introduced, the National Civil Code, 2017, was expected to bring a comprehensive and progressive interpretation of 'consideration' under contract law, but it failed to meet the expectations. The Code does not include a single word on the definition or essence of consideration. But, if some of the other provisions of The National Civil Code, 2017 are observed, the importance of consideration can be highlighted in the following ways:

\section{a. In the case of the lease contract}

If a contract is concluded under which a person gives any goods ${ }^{46}$ in which they have proper ownership and/or possession to another person for use and possession and enjoy the benefits accrued as a result in consideration for rent payable regularly for a certain period, then it is a lease contract. ${ }^{47}$

\begin{tabular}{|l|l|l|}
\hline Parties & Benefit & Detriment \\
\hline Lessor & payment & $\begin{array}{l}\text { Use, possession and } \\
\text { enjoyment of the goods. }\end{array}$ \\
\hline Lessee & $\begin{array}{l}\text { use, possession and } \\
\text { enjoyment of the goods }\end{array}$ & Payment \\
\hline
\end{tabular}

Consideration for lessor is a payment, and consideration for leasee is the goods to use possession and enjoy diminishing them. Therefore, it can be concluded that in the case of a lease contract in Nepal, consideration is essential.

\footnotetext{
46 The National Civil Code (n 2), s. 610, Explanation: "Goods" means, any property from which benefit may be acquired through consumption, possession or use without diminishing them.

47 Ibid, s. 610.
} 


\section{b. In the case of Hire-Purchase Contracts}

The hire-purchase contract is concluded if a person lets any goods ${ }^{48}$ to another person for hire. The hirer ${ }^{49}$ has the right to possession, and use of the goods let by the owner of the goods on the condition of payment of the rent amount by instalments periodically for those goods. ${ }^{50}$

\begin{tabular}{|l|l|l|}
\hline Parties & Benefit & Detriment \\
\hline owner of the goods & $\begin{array}{l}\text { payment of the amount by } \\
\text { installment }\end{array}$ & $\begin{array}{l}\text { Possession and use of } \\
\text { the goods. }\end{array}$ \\
\hline hirer & $\begin{array}{l}\text { Possession and use of the } \\
\text { goods. }\end{array}$ & Payment \\
\hline
\end{tabular}

Consideration for the hirer is a payment, and consideration for the owner of the goods is possession and use of the goods. The National Civil Code has given importance to consideration in Nepal.

\section{c. In the case of wages for employment in work}

While employing anyone ${ }^{51}$ in any work, the employer has to pay the wages in proportion to the work except in cases where the employee voluntarily agrees to work without wages. ${ }^{52}$

According to the above provision, it has not made the consideration compulsory; it has stated that the employee can voluntarily agree to work, but consideration can be taken by the employer.

\begin{tabular}{|l|l|l|}
\hline Parties & Benefit & Detriment \\
\hline Employee & Wages & service \\
\hline Employer & service & Payment for wages \\
\hline
\end{tabular}

Consideration for an employee is wages, and consideration for the employer is service. ${ }^{53}$ But in the case of employment in wage, there are no specific laws mentioning consideration in Nepal.

\section{d. Provision of unjust enrichment}

Another new concept introduced by the new civil code is unjust enrichment.

48 Ibid, s. 624(3), Explanation 1 states "Goods" means any movable property that may be let for hire for the purpose of its possession and use.

49 Ibid, s. 624(3), Explanation 2 states "Hirer" means a person who takes any goods on hire for possession and use according to the hire-purchase contract and also includes his or her successor in the event of his or her death or other third person to receive such goods under the contract.

$50 \quad$ Ibid, s. 624.

51 Ibid, s. 640 (1) States that 'Any person who has attained at least fourteen years of age may be employed in a work with his or her consent. But a person who has not attained sixteen years of age is not employed in a hazardous business or work.'

52 Ibid, s. 641.

53 Laxmi Sapkota. 'Ain ma Antarbirodh', Nagarik National Daily, Kathmandu, 18 February 2020. 
The lack of consideration might be understood as similar to unjust enrichment. Analyzing this is very important. Unjust enrichment means if any person gets any benefit or advantage from another person, without doing any lawful act or fulfilling any obligation, the person who so gets the benefit or advantage is said to have got an unjust enrichment. ${ }^{54}$

A person gets an unjust enrichment: $:^{55}$ if there is an increment in his or her property or decrease in his or her liability, if he or she receives a service from another or causes another to do work if another's property is used for him or her.

The person is not said to be unjustly enriched: ${ }^{56}$ if any goods, services, benefits or advantage can be obtained from any person under law or contract, if the person, from whom any goods, service, benefit or advantage have been obtained, has agreed with free consent not to take back or reimburse the same.

In determining whether or not and to what extent any person has got an unjust enrichment, no consideration is granted to any disadvantage or loss or damage caused thereby to him or her after he or she has got the unjust enrichment. ${ }^{57}$

However, before the National Civil Code, the court has given the decision in favor of unjust enrichment in the following cases:

\section{Yasasbi Shumsher JBR v. Bhaibars Developers Pvt. Ltd. ${ }^{58}$}

In the stated case the Supreme Court held that, money has the earning power. Parties have an obligation to about the the execution of the contract. No one can enrich themselves from other's money; hence, the doctrine of unjust enrichment is applied. Also, the doctrine of unjust enrichment does not support unjust profit from contractual agreement. Here, the defendant has set the order of priority relating to the fulfilment of her promise, which has been specified in the contract itself. Still, the party remains passive/does not inform about having fulfilled the promise and tries to be benefitted alone.

\section{Siddhartha Raj Panday v. Krishna Rana ${ }^{59}$}

Also in this case the Supreme Court held that when an individual is unjustly enriched, the law imposes an obligation upon the recipient to make restitution. The liability for unjust or unjustified enrichment arises irrespective of wrongdoing on the part of the recipient.

\footnotetext{
$54 \quad$ The National Civil Code (n 2), s. 664(1).

55 Ibid, s. 664(2).

56 Ibid, s. 664(3).

57 Ibid, s. 664(4).

58 Yasasbi Shumsher JBR v. Bhaibars Developers Pvt. Ltd, NKP 2074 (2017), volume 7, Decision no. 9847.

59 Siddhartha Raj Panday v. Krishna Rana, NKP 2073 (2016), volume 3, Decision no. 9556.
} 


\section{Lakshaman Kumar Yadav v. Rastriya Banijya Bank Limited, Central Office and Others ${ }^{60}$}

In this case the supreme court held that it would be unjust enrichment to the party, Rastriya Banijya Bank Limited. The service of data connectivity is already given by world link communication. Now, it has to receive the amount of the service given. The service has already been taken, and if the question of procedure is raised, then the party benefiting from the service will be unjustly enriched.

\section{The above legal provisions also show the importance and necessity of the consideration in the Nepal}

In Nepal, judicial interpretations and practices have developed the concept of consideration to some extent. However, if we see the landscape of contract law development, the essence of consideration is not seen as captivating and appealing. Previously, The Contract Act, 2056 B.S., section 2(d) had defined consideration as 'the promise made to do or not to do any work in return of doing or not doing any work mentioned in the proposal but, this Act has now been repealed. Hence, there was the need for more progressive law and interpretation in this matter.

\section{Conclusion}

Consideration means something in return in the contract. It is necessary to distinguish whether the transaction is fair or unfair. Further, consideration, in any transaction ensures the economic efficiency of the transaction. Also, the court sees the economic values for enforceability of the contract and an agreement is only a promise and not a contract in the absence of consideration.

The National Civil Code, 2017(2074) has the provision related to contract. The Contract Act, 2056 is quashed by it. This code has not included the definition of consideration. So, there is the question of the necessity of consideration in Nepal. The Contract Act, 2056, was also not clear about the necessity of consideration.

The consideration is absent in case of gift (reward, prize or tips, donation, payment of the compensation for the past work, promise to pay the time-barred debt, agency contract).

The consideration is essential in contract in Nepal can be proven in three ways: firstly, the theories, secondly, the precedent, and finally, the legislative provision.

The different theories of the considerations confirm the importance of the consideration. The bargain theory states that for consideration to be applied between the parties there must exist a promise or performance that is bargained in exchange for a promise. Correspondingly, the theory of reciprocity implies that consideration must

\footnotetext{
60 Lakshaman Kumar Yadav v. Rastriya Banijya Bank. Limited, Central Office and Others, NKP 2076 (2019), volume
} 3, Decision no. 10211. 
rely on something which the law must assume to be of some value to the promisor, in exchange for the proportional promise. Similarly, a 'nundum pactum' theory means the contract without consideration is the bare agreement and such bare agreement is not enforceable by law. Identically, the 'no consideration no contract' theory states that if there is no consideration then there is no contract.

The precedent shows the importance of consideration in Nepal. The Supreme Court has highlighted the importance of the consideration; in the case of, Bhagwan Lal Shab v. Harka Lal Giri, the court declared that the paper which lacks the consideration does not get validity of the contract paper. Also in the case of, Chitra Bahadur Karki, Proprietor of Manakamana Construction and Concerns Pvt. Ltd v. Maniram Aggrawal, Proprietor of Aggrawal Industries Pvt., the court set the precedent that, 'no consideration no contract', so, for the valid contract consideration is essential.

Unlike the Contract Act, 2056 (2000), the code does not include the definition of consideration; the code has not stated the necessity of lawful consideration in any specific provision. However, Consideration is essential in the lease contract, hire purchase, and wage contract of, The National Civil Code, 2017 (2074). In the case of a lease contract, there is the necessity of the consideration as consideration for lessor is payment and consideration for a lease is the goods to use possession and enjoy with diminishing them. Moreover, in the case of hire-purchase contracts, consideration for the hirer is payment and consideration for the goods' owner is possession and use of the goods. The National Civil Code has given importance to consideration in Nepal. As well as, in the case of wages for employment in work, it has not been considered compulsory; it has stated that the employee can voluntarily agree to work, but consideration can be taken by the employer. Consideration for an employee is wages, and consideration for the employer is service.

In addition, the doctrine of unjust enrichment is also included in the National Civil Code 2017 (2074) glorifying the importance of the consideration in Nepal. The doctrine of unjust enrichment is applicable in the following situations: a. the things taken by mistake to be returned (solutio indebiti), b. to pay back debt paid by mistake, c. to return goods or amount taken with mala fide intention and benefits accrued from that place, d. to pay debt paid by the third person, e. right to claim reimbursement if the payable tax is paid by another person, f. goods found may be kept upon giving information to the police.

At length, unquestionably, on the basis of the theory of consideration, on the basis of precedent, and on the basis of the provision of the National Civil Code, 2017 (2074) along with the provision of the doctrine of unjust enrichment, it can be proven that the consideration is essential in the contract in Nepal. 